Article

\title{
Techno-Economic Performance of Different Technological Based Bio-Refineries for Biofuel Production
}

\author{
Shemelis N. Gebremariam ${ }^{1}$, Trine Hvoslef-Eide ${ }^{2}$, Meseret T. Terfa ${ }^{3}$ and Jorge M. Marchetti ${ }^{1, *(1)}$ \\ 1 Faculty of Science and Technology (REALTEK), Norwegian University of Life Sciences, Drøbakveien 31, \\ 1432 Ås, Norway; Shemelis.nigatu.gebremariam@nmbu.no \\ 2 Department of Plant Sciences (IPV), Faculty of Biosciences, Norwegian University of Life Sciences, \\ Arboretveien 6, 1432 Ås, Norway; trine.hvoslef-eide@nmbu.no \\ 3 Department of Plant \& Horticultural Sciences, College of Agriculture, Hawassa University, P. O. Box 05, \\ Hawassa, Ethiopia; mesitesema@gmail.com \\ * Correspondence: jorge.mario.marchetti@nmbu.no
}

Received: 28 July 2019; Accepted: 11 October 2019; Published: 16 October 2019

\begin{abstract}
There are different technologies for biodiesel production, each having its benefits and drawbacks depending on the type of feedstock and catalyst used. In this study, the techno-economic performances of four catalyst technologies were investigated. The catalysts were bulk calcium oxide $(\mathrm{CaO})$, enzyme, nano-calcium oxide, and ionic liquid. The study was mainly based on process simulations designed using Aspen Plus and SuperPro software. The quantity and quality of biodiesel and glycerol, as well as the amount of biodiesel per amount of feedstock, were the parameters to evaluate technical performances. The parameters for economic performances were total investment cost, unit production cost, net present value (NPV), internal return rate (IRR), and return over investment (ROI). Technically, all the studied options provided fuel quality biodiesel and high purity glycerol. However, under the assumed market scenario, the process using bulk $\mathrm{CaO}$ catalyst was more economically feasible and tolerable to the change in market values of major inputs and outputs. On the contrary, the enzyme catalyst option was very expensive and economically infeasible for all considered ranges of cost of feedstock and product. The result of this study could be used as a basis to do detail estimates for the practical implementation of the efficient process.
\end{abstract}

Keywords: biodiesel; $\mathrm{CaO}$ catalyst; nano-catalyst; ionic liquid catalyst; economic analysis

\section{Introduction}

According to the recent report from the World Energy Outlook 2018 [1], 93\% of the world's carbon capacity is already in use up to 2040. Consequently, there is a very narrow space for the development of fossil fuel projects over this period without contradicting international objectives about climate change. This implies that it is becoming inevitable to push on the development of alternative and renewable energy resources for the supply of reliable and environmentally efficient energy to the growing economic activities around the world. Among such alternative sources are biofuels [2], which are mainly preferred for their carbon neutral character, their renewability, as well as the fact that they can be produced in decentralized manners from abundant and versatile resources. Biodiesel is one of the promising biofuels to substitute conventional fossil diesel. It has a number of environmental and technical benefits over conventional fossil diesel. Environmentally, biodiesel is non-toxic, biodegradable, and its greenhouse gas (GHG) emission is very low compared to the conventional fossil diesel $[3,4]$. The technical benefits are associated with its use for fuel; for example, 
its possession of more oxygen to favor complete combustion and its better lubricating character to reduce engine wear [5].

Biodiesel can be produced from different oil and fat resources, which are found everywhere. Such feedstocks include edible and non-edible plant oil, animal fat, as well as waste oils and fats. The production of fuel quality biodiesel from oil and fat feedstock mainly involves the transesterification reaction with alcohol in the presence of some kind of catalyst or without catalyst at the supercritical condition. The transesterification reaction catalyzed by homogeneous base catalysts like $\mathrm{NaOH}$ and $\mathrm{KOH}$ is the conventional way of producing biodiesel at an industrial scale [6], which requires relatively better-quality feedstock like edible oil with very low free fatty acid (FFA) content $[7,8]$. Such high-quality feedstock is usually associated with a high price. In addition, it creates food versus energy controversies. These reasons altogether have been making biodiesel the expensive alternative fuel compared to its counterpart-fossil diesel, because the cost of feedstock can take up to $80 \%$ of the total cost of biodiesel production $[9,10]$. Comparatively, the heterogeneous alkali-catalyzed transesterification reaction has advantages of easy catalyst recovery and reusability for multiple times [11,12]. Unlike the homogeneous ones, the heterogeneous alkali-catalyzed transesterification can tolerate a considerable amount of FFA in the feedstock. For instance, Avhad et al. [13] reported that using glycerol-enriched calcium oxide as a heterogeneous alkali catalyst, a $96.1 \%$ of crude Jatropha curcas oil containing high free fatty acid could be converted into biodiesel within $7 \mathrm{~h}$. In addition, most of such heterogeneous base catalyst types can be easily prepared from cheap resources, indicating the potential to reduce biodiesel production cost. For example, industrial wastes (red mud, slag, ash) and biological wastes (chicken eggshells, mollusk shells, animal bones) have huge potential towards developing a cheap catalyst for low-cost biodiesel production [14]. Among the heterogeneous alkali catalysts developed for biodiesel production, the main ones include basic zeolites, alkaline earth metal oxides, and hydrotalcites [15].

The conventional chemical catalyst options also include homogeneous and heterogeneous acid catalysts. In general, acid-catalyzed transesterification is very efficient in the production of biodiesel from feedstock with very high FFA content $[16,17]$. However, the problems usually associated with the use of acid catalysts are high reaction temperature, longer reaction time, and corrosion of the equipment due to the acid catalyst [10]. There are some substantial advantages of solid acid catalysts over the homogeneous ones. This includes ease of catalyst separation from the reaction media, which lowers product contamination and ease of catalyst regeneration and reuse, as well as much-minimized equipment corrosion [18].

The other most promising technologies for the production of biodiesel from least cost feedstock involve CaO-based catalysts, enzyme catalysts, ionic liquid (IL) catalysts, and nanoparticle catalysts. Calcium oxide, as a catalyst, has such advantages as an abundance occurrence, better catalytic property, easy separation from the product stream, reusability for multiple times, nontoxicity, and least cost character for feasible production of biodiesel from lower-quality feedstock [19,20]. Boey et al. [21] did a study on the production of biodiesel from waste cooking oil using a $\mathrm{CaO}$ catalyst derived from waste sources like mud crab shells and cockleshells. They calcined the $\mathrm{CaO}$ obtained from these wastes at $900{ }^{\circ} \mathrm{C}$ for $2 \mathrm{~h}$ separately and mixed them in a 1:1 mass ratio to catalyze the transesterification of the oil. According to their result, a $98 \%$ conversion could be achieved within $3 \mathrm{~h}$ for optimum reaction conditions of $5 \mathrm{wt} . \%$ catalyst and methanol to oil molar ratio of 13:1 at methanol refluxing temperature [21]. In another study, Sasiprapha et al. [22] assessed the production of biodiesel from used oil using $\mathrm{CaO}$ catalyst derived from river snail shells. For optimum reaction conditions of methanol to oil ratio of $9: 1$, catalyst amount of $3 \mathrm{wt} . \%$, and reaction temperature of $65^{\circ} \mathrm{C}$, they could achieve $92.5 \%$ conversion of oil to biodiesel within $3 \mathrm{~h}$ [22].

Even though the enzyme-catalyzed approach for biodiesel production is the expensive option, primarily due to the cost of the enzyme, the technical performance of most enzyme catalysts for the production of fuel quality biodiesel is very significant. Enzyme for the catalysis of biodiesel production has such advantages over the chemical catalysts as being less energy-intensive, allowing easy recovery of glycerol from the product stream and efficient conversion of acidic oil (oil with high FFA content) to 
biodiesel [23,24]. A study done by Cervero' et al. [25] indicated that a $95 \%$ conversion of soybean oil to biodiesel could be reached within $24 \mathrm{~h}$ using Novozyme 435 enzyme catalyst at optimum reaction conditions of $5 \mathrm{wt} . \%$ enzyme load, 3:1 molar ratio of ethanol to oil, and a temperature of $37^{\circ} \mathrm{C}$. Ketsara et al. [26] also studied the production of biodiesel from used palm oil using mixed enzymes in a solvent-free environment. The studied mixed enzyme contained Pseudomonas fluorescens and Candida rugose. According to their result, $89 \%$ conversion could be realized within $12 \mathrm{~h}$ for optimum reaction conditions of 3:1 ethanol to oil molar ratio, $10 \%$ enzyme dosage, $2 \%$ water content of the oil feedstock, and a $45^{\circ} \mathrm{C}$ reaction temperature [26].

The other group of promising catalysts for biodiesel production are ionic liquids, which are generally known as solvents and green catalysts in chemical processes. Several ionic liquids are being used for the catalysis of biodiesel production from various low-cost feedstock alternatives. The use of such ionic liquids for biodiesel production provides considerable advantages over most other catalyst categories. Some of such advantages are low corrosion of equipment, ease of separation, recyclability, and less wastewater production [27]. In addition, the lower reaction time, together with the ability to produce good quality biodiesel from low-cost feedstock, could make ionic liquid catalysis a better alternative than most of the catalyst options for biodiesel production. Feng et al. [28] studied the transesterification process to produce biodiesel from palm oil using Brønsted acidic ionic liquid as a catalyst. They found out that conversion of $98.7 \%$ of the oil to biodiesel could be achieved within $2.5 \mathrm{~h}$ when the optimum reaction conditions are methanol to oil molar ratio of 21:1, catalyst dosage of $3 \mathrm{wt} . \%$, and reaction temperature of $120^{\circ} \mathrm{C}$ [28]. In another study, Ullah et al. [29] investigated the production of biodiesel from waste palm cooking oil using the acidic ionic liquid as a catalyst. They used specific ionic liquid butyl-methyl imidazolium hydrogen sulfate $\left(\mathrm{BMIMHSO}_{4}\right)$ as catalyst, and the highest biodiesel yield of $95.6 \%$ could be achieved with optimum reaction conditions of $5 \mathrm{wt} . \%$ of $\mathrm{BMIMHSO}_{4}$, methanol to oil molar ratio of $15: 1,1 \mathrm{~h}$ reaction time at $160{ }^{\circ} \mathrm{C}$ reaction temperature and agitation speed of $600 \mathrm{rpm}$ [29].

Similarly, nano-catalysts are also becoming very interesting for the production of biodiesel from low-quality feedstock as they do have higher catalytic activity due to having large pore size and large surface area. Having large pore size and large surface area means possessing a more active catalytic surface, because the active surface of a catalyst, which is its vital property, increases when the size of the catalyst is reduced [30]. Such higher catalytic character enables the use of a smaller amount of the catalyst compared to other catalyst options, and this has considerable economic benefits for large-scale production processes. Generally, by using nano-catalysts, better conversion of oil feedstock to biodiesel can be achieved at relatively medium temperature and shorter reaction time. The study done by Bet-Moushoul et al. [31] indicated that the oil conversion range of $90 \%-97 \%$ could be attained within $3 \mathrm{~h}$ using $\mathrm{CaO}-$ based gold nanoparticles as a heterogeneous catalyst for transesterification of sunflower oil with methanol. For this conversion, the optimum reaction conditions were a reaction temperature of $65^{\circ} \mathrm{C}$, methanol to oil molar ratio of 9:1, and a catalyst loading of $3 \mathrm{wt} . \%$ [31]. Table 1 shows some of the recent studies done on the optimum reaction conditions required to produce biodiesel from different feedstock types using bulk $\mathrm{CaO}$, ionic liquid, enzyme, and nanoparticle catalysts. 
Table 1. Optimum reaction conditions for biodiesel production from different feedstock using four different catalyst categories: bulk CaO, enzyme, ionic liquid, and nanoparticle catalysts.

\begin{tabular}{|c|c|c|c|c|c|c|c|c|}
\hline \multirow{2}{*}{ Catalyst } & \multirow{2}{*}{ Feedstock } & \multirow{2}{*}{ Alcohol } & \multicolumn{3}{|c|}{ Optimum Reaction Conditions } & \multirow{2}{*}{ Conversion $(\%)$} & \multirow{2}{*}{ Time (h) } & \multirow{2}{*}{ Ref } \\
\hline & & & $\begin{array}{c}\text { Alcohol Molar } \\
\text { Ratio }\end{array}$ & $\begin{array}{c}\text { Catalyst } \\
\text { Amount (Wt.\%) }\end{array}$ & $\begin{array}{c}\text { Temperature } \\
\left({ }^{\circ} \mathrm{C}\right)\end{array}$ & & & \\
\hline Glycerol-enriched $\mathrm{CaO}$ & Jatropha oil & Methanol & 9:1 & 15 & 65 & 93.5 & 7 & [13] \\
\hline $\mathrm{CaO}$ & Vegetable oil & Methanol & $6: 1$ & 3 & 65 & 100 & 1.25 & [32] \\
\hline Activated $\mathrm{CaO}$ & Sunflower oil & Methanol & 13:1 & 3 & 60 & 94 & 1.67 & [33] \\
\hline $\mathrm{CaO}$ from river snail shell & $\mathrm{WCO}^{\mathrm{f}}$ & Methanol & $9: 1$ & 3 & 65 & 92.5 & 1 & [22] \\
\hline $\mathrm{CaO}$ from chicken manure & WCO & Methanol & $12: 1$ & 7.5 & 65 & 93 & 6.5 & [34] \\
\hline $\mathrm{CaO}$ from $\mathrm{WBCS}$ e & WCO & Methanol & $12: 1$ & 7 & 65 & 94.25 & 1 & [35] \\
\hline Novozyme 435 & Soybean oil & Ethanol & $3: 1$ & 5 & 37 & 95 & 24 & [25] \\
\hline Mixed Enzyme a & Used Palm oil & Ethanol & $3: 1$ & 10 & 45 & 89 & 12 & [26] \\
\hline Immobilized lipase & Canola oil & Methanol & $6: 1$ & 2.15 & 40 & 90 & 24 & [36] \\
\hline Pseudomonas fluorescens enzyme & Waste frying oil & Methanol & $3: 1$ & 5 & 45 & 63 & 24 & {$[37]$} \\
\hline$[$ Bmim $] \operatorname{Im}^{\mathrm{b}}$ & Vegetable oil & Methanol & $6: 1$ & 6 & 60 & 95 & 1 & [38] \\
\hline $4 \mathrm{~B}^{\mathrm{c}}$ & Vegetable oil & Ethanol & $9: 1$ & 5 & 60 & 94.3 & 5 & [39] \\
\hline$[\mathrm{Hnmm}] \mathrm{OH}^{\mathrm{d}}$ & Soybean oil & Methanol & $8: 1$ & 4 & 70 & 97 & 1.5 & {$[40]$} \\
\hline$\left[\mathrm{CyN} 1,1 \mathrm{PrSO}_{3} \mathrm{H}\right][\mathrm{p}-\mathrm{TSA}]$ & Palm oil & Methanol & $24: 1$ & 3 & 120 & 98.7 & 2.5 & {$[28]$} \\
\hline Imidazole-based IL & Tung oil & Methanol & $21: 1$ & 5 & 120 & 98 & 2 & [41] \\
\hline $\begin{array}{l}\text { Iron doped zinc oxide } \\
\text { nano-catalyst }\end{array}$ & Castor oil & Methanol & $12: 1$ & 14 & 55 & 91 & 0.833 & [42] \\
\hline $\mathrm{CaO} / \mathrm{Au}$ nanoparticles & Sunflower oil & Methanol & $9: 1$ & 3 & 65 & $90-97$ & 3 & [31] \\
\hline $\begin{array}{c}\text { Functionalized } \mathrm{CaO} \\
\text { nanoparticles }\end{array}$ & Canola oil & Methanol & $9: 1$ & 3 & 65 & 97 & 8 & [43] \\
\hline $\mathrm{KF} / \mathrm{CaO}$ catalyst & Tallow seed oil & Methanol & 12:1 & 4 & 65 & 97.5 & 2.5 & [44] \\
\hline
\end{tabular}

${ }^{a}$ Mixture of Pseudomonas fluorescens and Candida rugose; ${ }^{\mathrm{b}}$ Ionic liquid: 1-butyl-3-methylimidazolium imidazolide; ${ }^{\mathrm{c}}$ Ionic liquid: 1-benzyl-1H-benzimidazole; ${ }^{\mathrm{d}}$ Ionic liquid: 1-butyl-3-methyl morpholine hydroxide; ${ }^{\mathrm{e}} \mathrm{WBCS}$ - white bivalve clamshell; ${ }^{\mathrm{f}} \mathrm{WCO}$ - waste cooking oil. 
Even though these four catalyst categories are technically capable of producing fuel quality biodiesel from various feedstock options, the relative economic feasibility of each production alternative remains unclear, as there are no such considerable studies performed so far to investigate the economic competitiveness of the alternatives. Accordingly, this study aimed at evaluating the techno-economic performances of bulk $\mathrm{CaO}$, enzyme, ionic liquid, and nanoparticle catalyst technologies to produce biodiesel fuel from low-quality and cheap oil feedstock. The study would compare the proposed catalyst technologies in terms of their technological efficiencies and economic feasibility. Such an approach would give a complete view of the practicability of the process routes for sustainable production of biodiesel fuel. In addition, the study could be used as a preliminary estimate of the whole set up of the projects based on which detail estimates for the actual implementation of the efficient and affordable production process could be carried out. As to our knowledge, there are no similar investigations and comparisons performed among the catalyst technologies mentioned in this study.

The study was entirely based on process simulation involving all the unit procedures required to produce fuel quality biodiesel. These process simulations were designed using two commercial software - Aspen Plus and SuperPro. The technical performance evaluation was done based on the relative amount and purity of the product biodiesel and the byproduct glycerol, as well as the relative amount of biodiesel produced per amount of oil feedstock. Whereas the economic performance assessment was performed using economic parameters, such as total investment cost, unit production cost, net present value (NPV), internal rate of return (IRR), return over investment (ROI), and gross margin. The sensitivity of the technology options towards the change in market values of oil purchasing cost, catalyst purchasing cost, and biodiesel price was also assessed using NPV as a parameter.

\section{Materials and Methods}

\subsection{Description of Raw Materials}

The raw materials used in all the technological options include acidic oil feedstock, ethanol, and four catalyst types, such as bulk $\mathrm{CaO}$, enzyme (Novozyme 435), ionic liquid (1-benzyl-1H-benzimidazole-based IL), and nano-CaO (zinc doped $\mathrm{CaO}$ nanoparticle). We took acidic oil with $10 \%$ FFA content to represent the oil from most of the non-edible plants $[45,46]$, which are cheap and found everywhere. The alcohol considered was ethanol because it is non-toxic (thus easy to handle) and can be produced from renewable resources, making the biodiesel produced to be entirely from renewable resources.

The four catalyst categories considered in this study are proved to achieve the significant conversion of low-quality oil to biodiesel $[25,39,47,48]$. The bulk CaO-based catalyst can be prepared using cheap resources through very simple process steps like calcination [22]. Thus, we considered this catalyst because it is very cheap and can be easily prepared from waste materials. It can also be reused 13 times [49], favoring a considerable reduction of the total cost required for catalyst purchase. Concerning the nanoparticle catalyst category, we took a zinc doped nano-CaO catalyst because it does have additionally better catalytic activity due to its higher surface area [30,50]. Kumar et al. [48] found out that zinc doped $\mathrm{CaO}$ nano-catalyst could catalyze transesterification of oil with $8.4 \mathrm{wt} \%$ FFA content for its complete conversion. The third catalyst category considered was an enzyme, which is well known for its technical efficiency in producing fuel quality biodiesel from feedstock with very high FFA content $[51,52]$. In this study, we considered the commercial enzyme, Novozyme 435, produced from Candida antarctica. Li Deng et al. [53] studied the performances of different lipases with different alcohols to produce biodiesel from sunflower oil and found out that Novozyme 435 is preferable enzyme catalyst for the highest yield of fatty acid alkyl esters (with more than $90 \%$ yield) using methanol, ethanol, 1-propanol. Even though the cost of the enzyme is very high, the greater reusability rate of such catalysts would reduce the total cost required to purchase the enzyme catalyst. According to Andrade et al. [54], immobilized enzymes like Novozyme 435 could be reused 300 times, favoring the reduction of the total cost. The fourth catalyst considered was an ionic liquid catalyst, 
which is very well known to achieve higher conversion within relatively short reaction time when compared to most of the catalyst types used for biodiesel production $[27,29,41]$. In this specific study, we preferred to take the Bronsted acid ionic liquid, 1-benzyl-1H-benzimidazole, because this catalyst is proved to be one of the highly efficient catalysts compared to other ionic liquid catalysts [39]. This catalyst can be reused 8 times without a considerable reduction in its catalytic activity [39].

\subsection{Design Assumptions}

The process flow diagrams of all the production technology options were designed based on the following assumptions:

- The feeding rate of the oil feedstock was kept the same for all technological options, and it was $5177.23 \mathrm{~kg} / \mathrm{h}$. This value was assumed to represent large-scale production capacity considering that the oil feedstock has 10\% FFA on a molar basis; in that case, the feedstock consists of $5000 \mathrm{~kg}$ triglyceride and $177.23 \mathrm{~kg}$ FFA.

- It was assumed that there is no solid particle in the oil feedstock.

- The oil supply is continuous throughout the year.

- 7920 working hours or 330 working days per year were considered.

- In all of the equipment, the pressure drop was neglected.

- The triglyceride was represented by triolein with a density of $907.8 \mathrm{~kg} / \mathrm{m}^{3}$, the FFA was denoted by oleic acid with a density of $895 \mathrm{~kg} / \mathrm{m}^{3}$, and the pure biodiesel was denoted by ethyl oleate with a density of $873.9 \mathrm{~kg} / \mathrm{m}^{3}$.

- Due to the presence of polar compounds, such as ethanol and glycerol, in all of the processes considered, the non-random two liquid (NRTL) thermodynamic model was selected as the property package for the calculation of activity coefficient of the liquid phase in the simulations.

- The total project lifetime was assumed to be 15 years.

- There was no loan considered for all the projects.

- In each process option, the reusability of the catalysts was considered in the calculation of the total cost of catalyst.

\subsection{Description of the Technology Options for Biodiesel Production}

Four different catalyst options for biodiesel production from acid oil were considered in order to examine their techno-economic performances while producing fuel quality biodiesel from cheap oil. Technology option I: The enzyme-catalyzed transesterification and esterification; Technology option II: Bulk CaO-catalyzed transesterification; Technology option III: Ionic liquid-catalyzed transesterification; and Technology option IV: Nano-CaO-catalyzed transesterification. Recently, these catalyst technology options are getting more emphasis by researchers for efficient and eco-friendly production of biodiesel from cheap resources. In all the process alternatives, transesterification is the dominant reaction; however, other possible side reactions may occur based on the oil quality and the type of the catalyst used. The dominant reactions, the optimum reaction conditions, the amount and specific type of input materials, as well as the whole flow of the processes involved in each catalyst technology, are indicated as follows.

\subsubsection{Technology Option I}

This option was designed to investigate the techno-economic performance of the enzyme-catalyzed biodiesel production process by involving all the equipment necessary to get fuel quality biodiesel. Figure 1 indicates the process flow diagram of the enzyme catalysis technology option. 


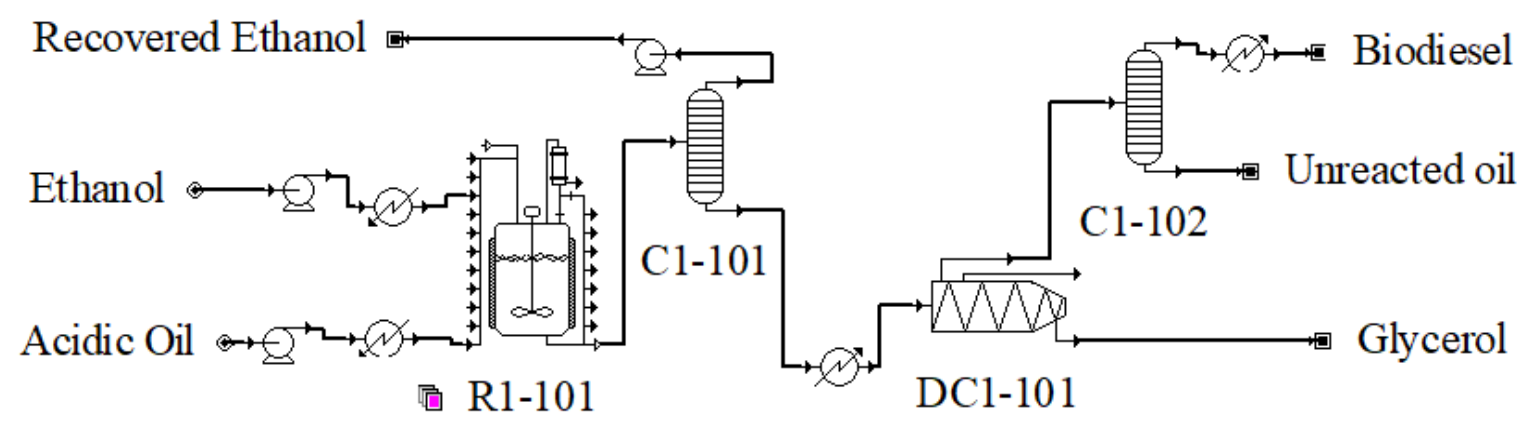

\begin{tabular}{|r|r|r|r|r|r|r|r|}
\hline Time Ref: $\mathbf{h}$ & & Acidic Oil & Ethanol & Biodiesel & Glycerol & Recovered Ethanol & Unreacted oil \\
\hline Type & & Raw Material & Raw Material & Revenue & Revenue & Credit & Credit \\
\hline Total Mass Flow & $\mathrm{kg}$ & 5177.23 & 809.20 & 5197.04 & 507.40 & 39.54 & 242.54 \\
\hline Temperature & ${ }^{\circ} \mathrm{C}$ & 25.0 & 25.0 & 25.0 & 38.5 & 78.3 & 359.2 \\
\hline Pressure & bar & 1.013 & 1.013 & 1.013 & 1.013 & 2.013 & 1.013 \\
\hline
\end{tabular}

Figure 1. Technology option I: R1-101 continuous stirred-tank reactor (CSTR) to produce biodiesel, C1-101 first short cut distillation column to recover unreacted ethanol, DC1-101 centrifugal decanter to separate glycerol, and C1-102 second short cut distillation column to purify biodiesel.

The dominant reactions involved in enzyme-catalyzed processes are transesterification and esterification. There was also hydrolysis of the triglyceride by water produced from the esterification reaction. Therefore, enzyme-catalyzed biodiesel production was comprised of two processes, namely: direct alcoholysis of triacylglyceride in one-step reaction and two-step hydrolysis of triacylglyceride followed by esterification [25].

The optimum reaction condition was taken to be $3: 1$ ethanol to oil molar ratio, $5 \mathrm{wt} . \%$ Novozyme 435 catalyst, and $37^{\circ} \mathrm{C}$ reaction temperature to attain about $95 \%$ oil conversion within $24 \mathrm{~h}$ [25]. The alcohol to oil molar ratio considered here was the exact stoichiometric amount (3:1) because an excessive amount of alcohol in the reaction could hinder the activity of the enzyme $[25,55]$. Especially when methanol is used as the reacting alcohol, the effect is more pronounced [25], and it is always recommended to perform stepwise ( 2 or 3 steps) addition of the alcohol to the reaction $[51,56]$. However, concerning ethanol alcohol, the effect is not that significant, and the one-step addition of the stoichiometric amount does not significantly affect the enzyme activity. This might be due to the lower amount of undissolved alcohol in the substrate when we use ethanol than methanol because it is much amount of undissolved alcohol that inhibits the enzyme activity [57]. Thus, since ethanol is more soluble in oil than methanol [58], enzyme inhibition effect is very low when we use ethanol than methanol. Cervero' et al. [25] also indicated that at maximum reaction time, the conversion of soybean oil to biodiesel was almost similar for both single step and multiple step addition of ethanol to the reaction. Accordingly, a one-step addition of the ethanol was considered in this process flow. This could also avoid the need to include more reactors, which would otherwise be if the alcohol is added in multiple steps.

Both the oil $(5177.23 \mathrm{~kg} / \mathrm{h})$ and ethanol $(809.35 \mathrm{~kg} / \mathrm{h})$ were heated up to $37^{\circ} \mathrm{C}$ and pumped separately to a continuous stirred-tank reactor (R1-101), which has a total volume of $33.6 \mathrm{~m}^{3}$ and packed with Novozyme 435 catalyst. The reactor was designed to have a constant temperature of $37^{\circ} \mathrm{C}$ and work continuously in such a way that the oil conversion of $95 \%$ could be achieved within a residence time of $24 \mathrm{~h}$ based on the optimum reaction conditions taken from the literature [25]. The produce from the reactor was then directed to the first distillation column (C1-101) to recover the unreacted ethanol for possible reuse and to improve the biodiesel quality too. The bottom outlet from this distillation column was cooled down and directed into a centrifugal decanter (DC1-101) to separate the glycerol. The upper output from this centrifugal decanter was then taken to the second short cut distillation column (C1-102) to purify the biodiesel. This distillation column was designed to have 11 number of stages and 0.125-reflux ratio for which the maximum possible biodiesel purification could be attained. 


\subsubsection{Technology Option II}

The second technological option considered the application of bulk $\mathrm{CaO}$ catalyst to produce biodiesel through transesterification of acidic oil by involving all unit procedures required to get high-quality fuel. Figure 2 indicates the flow diagram of the whole processes involved to produce biodiesel fuel using the $\mathrm{CaO}$ catalyst.

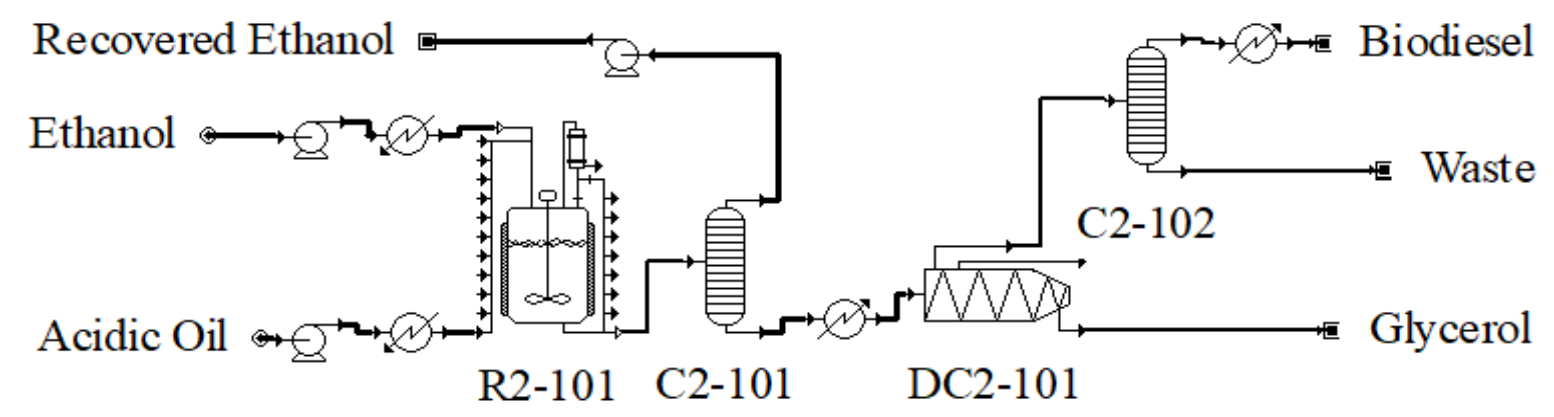

\begin{tabular}{|r|r|r|r|r|r|r|r|}
\hline Time Ref: $\mathbf{h}$ & & Acidic Oil & Ethanol & Biodiesel & Glycerol & Recovered Ethanol & Waste \\
\hline Type & & Raw Material & Raw Material & Revenue & Revenue & Credit & \\
\hline Total Mass Flow & $\mathrm{kg}$ & 5177.2300 & 2341.3500 & 5132.4253 & 503.2338 & 1624.0040 & 276.5980 \\
\hline Temperature & ${ }^{\circ} \mathrm{C}$ & 25.0 & 25.0 & 25.0 & 26.7 & 52.5 & 259.0 \\
\hline Pressure & $\mathrm{bar}$ & 1.013 & 1.013 & 0.150 & 1.013 & 3.750 & 0.150 \\
\hline
\end{tabular}

Figure 2. Technology option II: R2-101 CSTR for the production of biodiesel, C2-101 first short cut distillation column to recover excess ethanol, DC2-101 centrifugal decanter to separate the glycerol, and C2-102 second short cut distillation column to purify the biodiesel.

In this technology option, the dominant reaction was a CaO-catalyzed transesterification reaction for which excess amount of ethanol was used to favor forward reaction for more biodiesel production [20,32]. There was also an unavoidable saponification reaction between the FFA and the catalyst, which could not be dominant due to the relatively lower amount of FFA. The reactor designed was a continuous stirred-tank reactor packed with a bulk $\mathrm{CaO}$ catalyst. The optimum reaction conditions taken into consideration were oil to ethanol molar ratio of 9:1, catalyst loading of $7 \mathrm{wt} . \%$ with respect to oil, and reaction temperature of $75^{\circ} \mathrm{C}$; and at such reaction conditions, $97.58 \%$ oil conversion could be achieved within $2 \mathrm{~h}$ [47].

Oil amount at $5117.23 \mathrm{~kg} / \mathrm{h}$ and the ethanol amount at $2341.35 \mathrm{~kg} / \mathrm{h}$ were heated up to $75{ }^{\circ} \mathrm{C}$ separately and pumped into the continuous stirred-tank reactor (R2-101), which has a total volume of $18.9 \mathrm{~m}^{3}$ and packed with bulk $\mathrm{CaO}$ catalyst. The reactor was designed to have a $75{ }^{\circ} \mathrm{C}$ constant temperature. The outlet from the reactor was directed to the first distillation column (C2-101) to separate the excess ethanol for reuse. Seven stages and 2-reflux ratio were the optimum values taken in the design of this distillation column to recover the maximum possible ethanol left after the reaction. The lower pipe from this distillation column was directed to a centrifugal decanter (DC2-101) for glycerol separation from the product mixture. The upper outlet from this centrifugal decanter was then directed to the second distillation column (C2-102) for purification of the biodiesel product. This distillation column was designed with 4 number of stages and 3 reflux ratios, beyond which there could not be further purity of the biodiesel attained. The waste stream from this process was composed of unconverted oil and calcium soap, which is non-toxic and rather useful if further purification is included. However, such an additional purification unit procedure incurs the considerable cost and would increase the overall production cost, making the technology option economically unattractive.

\subsubsection{Technology Option III}

In this technology option, the ionic liquid-catalyzed biodiesel production process was designed for techno-economic evaluation of the possible arrangement of all equipment required to produce fuel 
quality biodiesel. Figure 3 indicates the whole flow diagram required to produce fuel quality biodiesel using a specific type of ionic liquid catalyst.

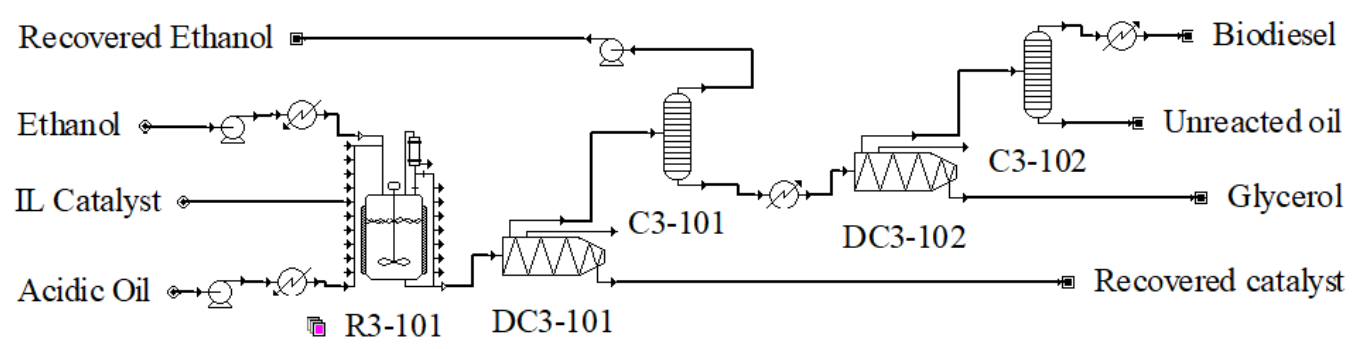

\begin{tabular}{|r|r|r|r|r|r|r|r|r|r|}
\hline Time Ref: $\mathbf{h}$ & & Acidic Oil & Ethanol & lonic Liquid Catalyst & Biodiesel & Glycerol & Recovered ethanol & Recovered Catalyst & Unreacted oil \\
\hline Type & & Raw Material & Raw Material & Raw Material & Revenue & Revenue & Credit & Credit & Credit \\
\hline Total Mass Flow & $\mathrm{kg}$ & 5177.2300 & 2428.0700 & 89.0000 & 5104.1441 & 490.1182 & 1674.3256 & 89.0761 & 336.7259 \\
\hline Temperature & ${ }^{\circ} \mathrm{C}$ & 25.0 & 25.0 & 25.0 & 25.0 & 26.7 & 78.3 & 60.0 & 101.0 \\
\hline Pressure & bar & 1.013 & 1.013 & 1.013 & 1.013 & 1.013 & 4.513 & 1.000 & 1.013 \\
\hline
\end{tabular}

Figure 3. Technology option III: R3-101 CSTR for the production of biodiesel, DC3-101 first centrifugal decanter to recover the catalyst, C3-101 first distillation column to recover excess ethanol, DC3-102 second centrifugal decanter to separate the glycerol, and C3-102 second short cut distillation to purify the biodiesel.

Transesterification was the dominant reaction considered here, even though there was also an esterification reaction due to the presence of FFA in the oil. The optimum reaction condition taken into consideration for this process option was 9:1 ethanol to oil molar ratio, $5 \%$ (based on mmol of oil) catalyst, and $60^{\circ} \mathrm{C}$ reaction temperature to attain a maximum conversion $(94.3 \%)$ of the oil within $5 \mathrm{~h}[39]$.

Oil with a rate of $5177.23 \mathrm{~kg} / \mathrm{h}$ and ethanol with a rate of $2428.07 \mathrm{~kg} / \mathrm{h}$ were heated up to $60^{\circ} \mathrm{C}$ separately and pumped into CSTR (R3-101), which has a total volume of $23.7 \mathrm{~m}^{3}$ and to which a Brønsted acid ionic liquid (1-benzyl-1H-benzimidazole) catalyst was also supplied at a rate of $258.86 \mathrm{~kg} / \mathrm{h}$. The reactor was designed to work at a constant temperature of $60^{\circ} \mathrm{C}$. The product from this reactor was directed into the first centrifugal decanter (DC3-101) for the separation of the catalyst from the remaining product mixture. The upper outlet from this centrifugal decanter was let into the first short cut distillation column (C3-101) to recover the leftover ethanol for recycling. This column was designed to have 5 number of stages and 3.5-reflux ratio, above which there was no change in amount and quality of ethanol recovered. The bottom output from this first distillation column was then directed to the second centrifugal decanter (DC3-102) to separate glycerol. The upper outlet from the second centrifugal decanter was let into the second distillation column (C3-102) for the purification of the biodiesel product. This distillation column was designed to have 7 actual stages and 0.125 reflux ratio by which the maximum possible purity could be attained.

\subsubsection{Technology Option IV}

As the fourth technology option, the nano-CaO-catalyzed process was designed to assess the techno-economic performance for the production of fuel quality biodiesel. Figure 4 indicates the whole process flow diagram of producing fuel quality biodiesel using zinc doped $\mathrm{CaO}$ nano-catalyst. 


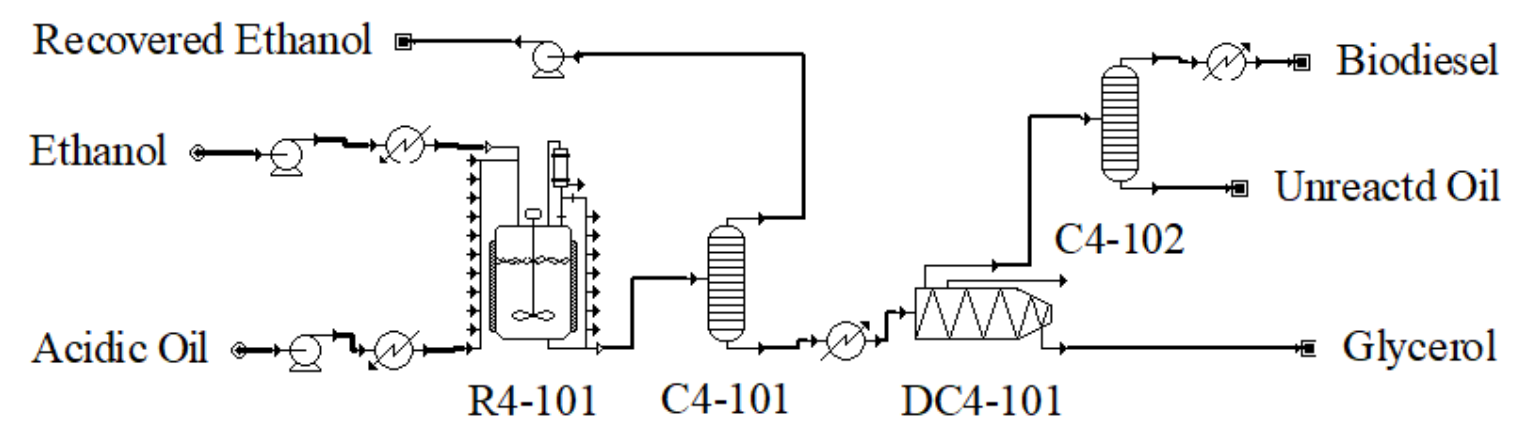

\begin{tabular}{|r|r|r|r|r|r|r|r|}
\hline Time Ref: $\mathbf{h}$ & & Acidic Oil & Ethanol & Biodiesel & Recovered Ethanol & Unreactd Oil & Glycerol \\
\hline Type & & Raw Material & Raw Material & Revenue & Credit & Credit & Revenue \\
\hline Total Mass Flow & $\mathrm{kg}$ & 5177.2300 & 2341.3500 & 5202.9529 & 1569.8496 & 232.2409 & 513.6241 \\
\hline Temperature & ${ }^{\circ} \mathrm{C}$ & 25.0 & 25.0 & 25.0 & 78.3 & 353.1 & 26.5 \\
\hline Pressure & bar & 1.013 & 1.013 & 1.013 & 4.513 & 1.013 & 1.013 \\
\hline
\end{tabular}

Figure 4. Technology option IV: R4-101 CSTR for the production of biodiesel, C4-101 first short cut distillation column to recover excess ethanol, DC4-101 centrifugal decanter to separate the glycerol, and C4-102 second distillation column to purify the biodiesel.

Transesterification was the dominant reaction using the nano-CaO catalyst. According to the study done by Kumar et al. [48], the existence of a saponification reaction among the specific catalyst, zinc doped $\mathrm{CaO}$, and the FFA in the oil is negligible. The optimum reaction condition for $99 \%$ conversion of the oil within $1 \mathrm{~h}$ was taken to be the molar ratio of ethanol to the oil of 9:1, catalyst amount of 5 wt. $\%$ with respect to oil, and $65^{\circ} \mathrm{C}$ as the reaction temperature [48].

The oil at a feeding rate of $5177.23 \mathrm{~kg} / \mathrm{h}$ and ethanol at a rate of $2341.35 \mathrm{~kg} / \mathrm{h}$ were heated up to $65^{\circ} \mathrm{C}$ separately and driven into the continuous stirred-tank reactor (R4-101), which has a total volume of $9.4 \mathrm{~m}^{3}$ and packed with zinc doped $\mathrm{CaO}$ nano-catalyst. The rector was designed to work at a constant temperature at $65^{\circ} \mathrm{C}$. The produce coming out of the reactor was directed into the first distillation column (C4-101) to distill out the excess ethanol for reusing. This column was designed to have 4 number of stages and 1 reflux ratio for the maximum possible recovery of the excess ethanol. The bottom outlet from the first distillation column was cooled down to ambient temperature and directed to a centrifugal decanter (DC4-101) for the separation of the glycerol from the rest of the mixture. Finally, the upper outlet from this centrifugal decanter was directed into the second short cut distillation column (C4-102) to purify the biodiesel from impurities, such as unreacted oil and remaining glycerol. This distillation column was designed to have 7 stages and 0.2 reflux-ratio at which the maximum possible purity of the biodiesel product could be achieved.

In all the production technology options, the storage tanks for raw materials and output were not involved because the raw materials are considered to be used immediately, and the outputs could also be used as soon as they are produced without the need to store them. In most of the process options, there was no waste stream from the production, except in technology option II, where the waste stream was composed of unreacted oil and calcium soap. This waste stream could be purified further to get reusable oil and economically valuable calcium soap. Calcium soap is vital as fat supplements for ruminants because it comprises a high concentration of fat and calcium, and both are beneficial for ruminants [59].

\subsection{Techno-Economic Assessment}

The technical performances of the technology options were evaluated based on the relative amount and purity of biodiesel product and glycerol byproduct while using the same amount and quality of oil feedstock. The other important parameter considered was the quantity of biodiesel that could be 
produced from a kilogram of the oil feedstock. Such technical performance assessment depends on the material and energy balance, which was done using Aspen plus V10 considering optimum reaction conditions of the dominant reactions in each technology option.

The economic analysis of the processes was carried out using SuperPro software. By using financial input data, the program calculated the internal return rate (IRR) (before and after-tax), NPV (at 7\% interest rate), gross margin, unit production cost, and annual revenue, among other important economic parameters. The latest market values and the estimated cost of raw materials, utilities, labor, and equipment were used as the basis for evaluating the economic performances of the studied technology options. The other considerable cost categories for such evaluation were equipment installation cost, auxiliary facilities cost, and depreciation cost, among others. The feedstock taken was non-edible and cheap oil with an estimated cost in the range of 478-684 US\$/ton $[45,46,60]$. In this specific study, feedstock cost of $580 \mathrm{US} \$ / \mathrm{kg}$ was taken as the average value because it is very cheap to produce such oil in the Ethiopian context, even though there is no formal market to buy or sell non-edible oil in the country. The delivered cost of the other raw materials, such as the four catalysts and ethanol, were based on the latest market prices taken from various sellers in Ethiopia, as well as from the relevant literature $[54,61]$.

The costs of all the required labor categories are according to the current wage indicator in Ethiopia [62], for which the conversion to US\$ was done based on the rate at the time of referring the database. The labor cost was calculated using the basic rates allocated for each labor category. In doing so, the basic rate was multiplied by the sum of the benefit, supervision, supplies, and administration rates, as well as the total labor hours. In all the technology options, the percent of work time dedicated to process-related activities, which is used to estimate the labor time, was taken to be $70 \%$, considering that the technology options involve continuous processes. The utilities considered in all the technology options include electricity, steam, steam high, and cooling water, and their cost estimations were taken according to the current market prices in Ethiopia as well as from the relevant literature $[63,64]$. Table 2 shows the estimated costs for utilities, labor, and raw materials considered in all the technology options.

Table 2. The estimated cost of raw materials, labor, and utilities used in the four technology options.

\begin{tabular}{cc}
\hline Raw Materials & Cost \\
\hline Oil & $0.478 \mathrm{US} \$ / \mathrm{kg}$ \\
Ethanol & $0.300 \mathrm{US} \$ / \mathrm{kg}$ \\
Bulk CaO & $0.120 \mathrm{US} \$ / \mathrm{kg}$ \\
Ionic Liquid & $50.5 \mathrm{US} \$ / \mathrm{kg}$ \\
Enzyme (Novozyme 435) & $1000 \mathrm{US} \$ / \mathrm{kg}$ \\
Nano-CaO & $6.5 \mathrm{US} \$ / \mathrm{kg}$ \\
Utilities & \\
Electricity & $0.021 \mathrm{US} \$ / \mathrm{KW}-\mathrm{h}$ \\
Steam high & $10 \mathrm{US} \$ \mathrm{MT}$ \\
Steam & $6 \mathrm{US} \$ / \mathrm{MT}$ \\
Cooling water & $0.025 \mathrm{US} \$ / \mathrm{MT}$ \\
Labor (Basic rate) & \\
Reactor operator & $15 \mathrm{US} \$ / \mathrm{h}$ \\
Operator & $10 \mathrm{US} \$ / \mathrm{h}$ \\
\hline
\end{tabular}

The cost of every equipment involved in all technology options was estimated using the Peter and Timmerhaus method [65]. For such estimation, the Chemical Engineering Plant Cost Index of 691.8 for February 2019 was used [66]. This index signifies the money time value due to deflation and inflation by which the average cost of each equipment can easily be calculated for the year 2019 using previous year cost values. For the estimation of the other components of the capital investment cost like instrumentation, piping, electricity, installation, and yard improvement, a method involving allocation of a percentage of total equipment purchasing cost was used based on literature, as shown in Table 3. 
Table 3. Direct plant cost categories and their percentage allocation with equipment cost [67].

\begin{tabular}{cc}
\hline Cost Category & \% Allocation with Equipment \\
\hline Piping & 20 \\
Instrumentation & 10 \\
Electrical & 15 \\
Insulation & 3 \\
Building & 15 \\
Yard improvement & 10 \\
Auxiliary facilities & 25 \\
Unlisted equipment & 20 \\
\hline
\end{tabular}

These capital investment cost categories could directly be used in SuperPro because its cost estimation interface gives options to assign an estimated percent of total equipment cost for each direct plant cost category. The other equipment-associated costs, such as insurance, depreciation, maintenance cost, and tax, could also be put in the software based on the percentage allocation of their costs, as indicated in Table 4.

Table 4. Cost estimation methods for components of capital investment and operating costs.

\begin{tabular}{cc}
\hline Cost Items & Estimation Method \\
\hline Capital investment cost categories & \\
Installation cost (for each equipment) & $0.2 \times \mathrm{PC}^{\mathrm{h}}$ \\
Maintenance cost (for each equipment) & $0.1 \times \mathrm{PC}$ \\
Purchasing cost of unlisted equipment (PCUE) & $0.2 \times \mathrm{PC}$ \\
Installation cost of unlisted equipment & $0.5 \times \mathrm{PCUE}$ \\
Operating cost categories & $2 \times \mathrm{DFC}^{\mathrm{i}}$ \\
Insurance & $15 \times \mathrm{DFC}$ \\
Local tax & $5 \times \mathrm{DFC}$ \\
Factory expense & $30 \times \mathrm{TLC}^{\mathrm{j}}$ \\
\hline
\end{tabular}

${ }^{\mathrm{i}}$ DFC-direct fixed cost; ${ }^{\mathrm{h}}$ PC-equipment purchasing cost; ${ }^{\mathrm{j}}$ TLC-total labor cost.

\section{Results and Discussion}

The material and energy balance of the four technology options were carried out based on determined equipment size and the optimum reaction conditions taken for each dominant reaction in the processes. Using the results from material and energy balance together with the latest prices of raw materials, utilities, labor, and equipment, the techno-economic performances of the technology options have been evaluated and presented as follows.

\subsection{Technical Performances}

All the process options could provide fuel quality biodiesel and pure glycerol, proving that the catalysts used together with the unit procedures involved in separation and purification of the crude biodiesel could attain high-quality products. Accordingly, the biodiesel from all technology options fulfilled the American Society for Testing and Materials (ASTM) standards for biodiesel fuel quality. However, there was a slight variation in the amount of biodiesel and glycerol produced. In terms of biodiesel product, technology option IV had the highest performance, with about $98.98 \mathrm{~kg} / \mathrm{h}$ product variation from the least performing one. This was mainly owing to the high catalytic activity of the nano-CaO particles, which favors the high conversion of the oil into biodiesel within relatively short reaction time. It might also be due to the negligible occurrence of the saponification reaction when zinc doped nano-CaO catalyst was used [48], which also minimizes the likeliness of the catalyst being used by the FFA in the process of saponification. Relatively, the least performance in terms of biodiesel 
product was indicated in the ionic liquid catalyst option. This was due to the lower conversion percentage achieved in the given optimum reaction conditions taken from the literature [39].

Similarly, the higher glycerol production amount was attained in technology option IV, with a product variation of $23.43 \mathrm{~kg} / \mathrm{h}$ glycerol from the least performing option. This was again due to the variation in the achievement of oil conversion percentage according to the required optimum reaction conditions. Consequently, the option I and IV did have a relatively highest performance as they provided more amount of biodiesel from the same amount of feedstock used. Table 5 indicates the relative technical performances of the technology options studied.

Table 5. Summary of technical performances of the technology options.

\begin{tabular}{ccccc}
\hline \multirow{2}{*}{ Indicators } & \multicolumn{4}{c}{ Technology Options } \\
\cline { 2 - 5 } & Option I & Option II & Option III & Option IV \\
\hline Biodiesel amount (kg/h) & 5191.26 & 5132.16 & 5103.64 & $5202 . .62$ \\
Biodiesel quality (\% mass) & 99.9 & 99.9 & 99.9 & 99.9 \\
Glycerol amount (kg/h) & 507.47 & 503.06 & 489.98 & 513.41 \\
Glycerol quality (\% mass) & 99 & 99 & 99 & 99 \\
Performances (biodiesel/oil) & 1 & 0.991 & 0.986 & 1 \\
Impurities in biodiesel * & & & & \\
Glycerol (\% mass) & 0.11 & 0 & 0.01 & 0 \\
Triolein (\% mass) & 0 & 0 & 0 & 0 \\
\hline
\end{tabular}

* The maximum allowable amount of impurities, according to ASTM (American Society for Testing and Materials,) are Glycerol $0.25 \%$ mass and Triolein $0.20 \%$ mass.

The catalysts from all the technology options could be recovered and reused for a number of times. This would help to reduce a considerable amount of money, which otherwise could be spent to purchase the extra catalyst. Another advantage of the processes was that in all the process options, except technology option II, there was no waste produced. In option II, the waste stream was composed of unreacted oil and calcium soap that could be further purified for economic benefits. The unreacted oil from technology option I and option III could be recycled directly to the processes, whereas the one from technology option IV should pass through a treatment step before it is reused in order to reduce the FFA content. This is because $76 \%$ of the unreacted oil from this process was composed of FFA, which was left unreacted in the nano-catalysis process.

\subsection{Economic Performances}

Technology option I was the most expensive alternative, mainly due to the very high cost of the enzyme, Novozyme 435. Even though this catalyst could be repeatedly used for more than 200 times [54], and the process could give the second higher biodiesel product, the higher total investment cost of the option could not make it economically feasible for the production of biodiesel fuel. The higher production cost in option I was also attributed to its relatively larger reactor volume required due to longer reaction time. Because the larger the equipment volume, the higher would be the costs of equipment, facilities, and utilities.

The second expensive option was the technology option III. Its total investment cost was almost half of that of the option I and 37\% higher than the least cost option, which was option II. This was mainly because of the second larger volume of reactor required due to longer reaction time as well as because of additional centrifugal decanter required to separate the catalyst. The larger and the more equipment we use, the higher would be the utility cost and the other equipment-associated costs. Technology option II had the least total capital investment cost because it required smaller equipment sizes due to minimum reaction time, and the catalyst involved was the cheapest among the catalyst options studied.

Even though technology option IV was the second cheapest option, the higher cost of the nano-CaO catalyst could still make it economically infeasible at the optimum market prices of raw materials 
and outputs. Similarly, option III was also found to be economically infeasible at the current market prices of raw materials and outputs. However, for the optimum market values of inputs and outputs considered, option II was the most feasible option with positive NPV, lower unit production cost, higher IRR, ROI, and gross margin. Table 6 summarizes the economic performances of the technology options. It highlights the comparative economic performances of the process options for the given market scenario. The first part indicates the total investment cost, followed by expenditures in cost categories. The calculated revenues from the product and byproduct, as well as the value of the calculated economic parameters, are also indicated in the Table.

Table 6. Summary of the economic performance of the technology options.

\begin{tabular}{ccccc}
\hline Economic Performance Parameters & \multicolumn{3}{c}{ Catalyst Technology Options } \\
\cline { 2 - 5 } & Option I & Option II & Option III & Option IV \\
\hline Total capital investment cost (US\$) & $13,200,448$ & $4,608,642$ & $6,319,464$ & $4,744,425$ \\
Total equipment purchasing cost (US\$) & $1,629,303$ & 432,295 & 674,025 & 403,033 \\
Direct fixed capital (US\$) & $6,716,375$ & $1,781,747$ & $2,778,061$ & $1,682,115$ \\
Working capital (US\$) & $6,148,254$ & $2,737,807$ & $3,402,499$ & $2,978,204$ \\
Total annual operating cost (US\$) & $71,304,387$ & $31,224,324$ & $39,050,943$ & $33,824,494$ \\
Total annual raw material cost (US\$) & $66,706,623$ & $29,372,952$ & $36,670,506$ & $32,010,394$ \\
Labor dependent cost (US\$) & 624,549 & 364,320 & 390,343 & 364,320 \\
Facility dependent cost (US\$) & $3,376,225$ & 889,148 & $1,396,347$ & 844,949 \\
Utility cost (US\$) & 187,365 & 109,296 & 117,103 & 109,296 \\
Laboratory, quality control, and analysis (US\$) & 299,626 & 378,608 & 366,644 & 385,535 \\
Annual revenue from Biodiesel (US\$/year) & $32,087,761$ & $31,704,748$ & $31,529,636$ & $32,140,209$ \\
Annual revenue from Glycerol (US\$/year) & $1,607,422$ & $1,594,245$ & $1,552,758$ & $1,627,161$ \\
Total annual revenue (US\$/year) & $33,695,184$ & $33,298,993$ & $33,082,394$ & $33,767,370$ \\
Unit production revenue (US\$/kg) & 0.8186 & 0.8192 & 0.8184 & 0.8194 \\
Unit production cost (US\$/kg biodiesel) & 1.7323 & 0.7681 & 0.9660 & 0.8208 \\
Net Present Value at 7\% (US\$) & $-349,847,116$ & $9,736,266$ & $-57,834,235$ & $-3,217,935$ \\
Return over Investment (\%) & 26.11 & 84.66 & 71.48 & 103.69 \\
After tax Internal Rate of Return (\%) & -100 & 32.73 & -100 & -100 \\
Gross margin (\%) & 13.79 & 17.53 & 20.19 & 21.93 \\
\hline
\end{tabular}

The higher amount of biodiesel product and glycerol byproduct for the nano-CaO-catalyzed option results in a relatively higher value of total annual revenue incurred, as shown in Table 6. The lowest total annual revenue was recorded for ionic liquid-catalyzed option with about 684,976 US\$/year lower than the revenue from the nano-catalyzed option. The enzyme-catalyzed option scored the highest unit production cost with about 0.964 US\$ increment per kilogram of biodiesel product compared to the bulk CaO-catalyzed option. Positive after-tax IRR was recorded only for bulk CaO-catalyzed option. For the enzyme-catalyzed option, the gross margin, ROI, and NPV were the lowest, followed by the ionic liquid-catalyzed option.

Except for the bulk CaO-catalyzed option, the other three process options showed negative NPV. This indicated that the investment of each project was not profitable because the present value of the net cash flow in each project, within the projects' lifetime, was lower than the present initial cash required to establish them. This was exhibited more by the values of IRR for each process option. The after-tax IRR of the bulk CaO-catalyzed option was positive, whereas, for the other three options, the calculated amount was negative, meaning that the projects did not perform well over time. For instance, without considering the discounted cash flow, i.e., only based on the amount of return and cost of investment, the nano-CaO-catalyzed option seemed efficient as it had a higher percentage of ROI. However, its NPV and IRR were negative, implying that the investment in this process option is not viable within the given lifetime.

Concerning the relative economic performances of the technologies, divergent results might be obtained if calculations are done in a different market scenario or using market values of inputs 
and outputs, which are not comparable to what has been used in this study. This implies that such performances are expected to be different for countries with different market scenarios.

\subsection{Sensitivity Analysis}

The economic feasibility of the studied technology options was very diverse, mainly due to the cost variation among the catalysts as well as the number and size of equipment required to attain fuel quality biodiesel. Thus, it seems reasonable to test how sensitive the technology options are towards the change in market values of the inputs and outputs. Among the various economic variables, oil cost and catalyst cost comprise the higher percentage of the raw materials' cost. Similarly, biodiesel is the main product to get the desired revenue from the projects. Therefore, in this study, the economic effect of variations of oil purchasing cost, biodiesel selling price, and catalyst purchasing cost was evaluated in terms of NPV (at 7\% interest rate); and the results among the technology options were compared and presented as follows. We considered biodiesel price since biodiesel is the main product, and its price fluctuation could have a direct effect on the feasibility of the businesses. We considered oil cost because the cost of feedstock took a higher share of raw material cost. In addition, we took the cost of catalysts for sensitivity analysis in order to indicate how the respective cost of the studied catalysts affect the businesses as well as to indicate the maximum possible cost of each catalyst for the economic feasibility of the businesses.

\subsubsection{Effect of Change of Oil Cost on NPV}

The trend at which the technology options respond towards change in oil purchasing cost was almost similar. However, the option I was found to be economically infeasible for all ranges of the oil purchasing cost considered. For option III, the maximum cost of oil feedstock was about $0.39 \mathrm{US} \$ / \mathrm{kg}$, beyond which the option would be economically infeasible. Option II was found to be more tolerant of the market variation of oil cost. It could, still, be economically feasible up to $0.59 \mathrm{US} \$ / \mathrm{kg}$ of the oil purchasing cost. In comparison, option IV was found to be the second most tolerant of market fluctuations of the oil purchasing cost. Nevertheless, it could be economically feasible for oil purchasing cost less than $0.51 \mathrm{US} \$ / \mathrm{kg}$. Figure 5 indicates the effect of the change in oil purchasing cost on NPV of the technology options.

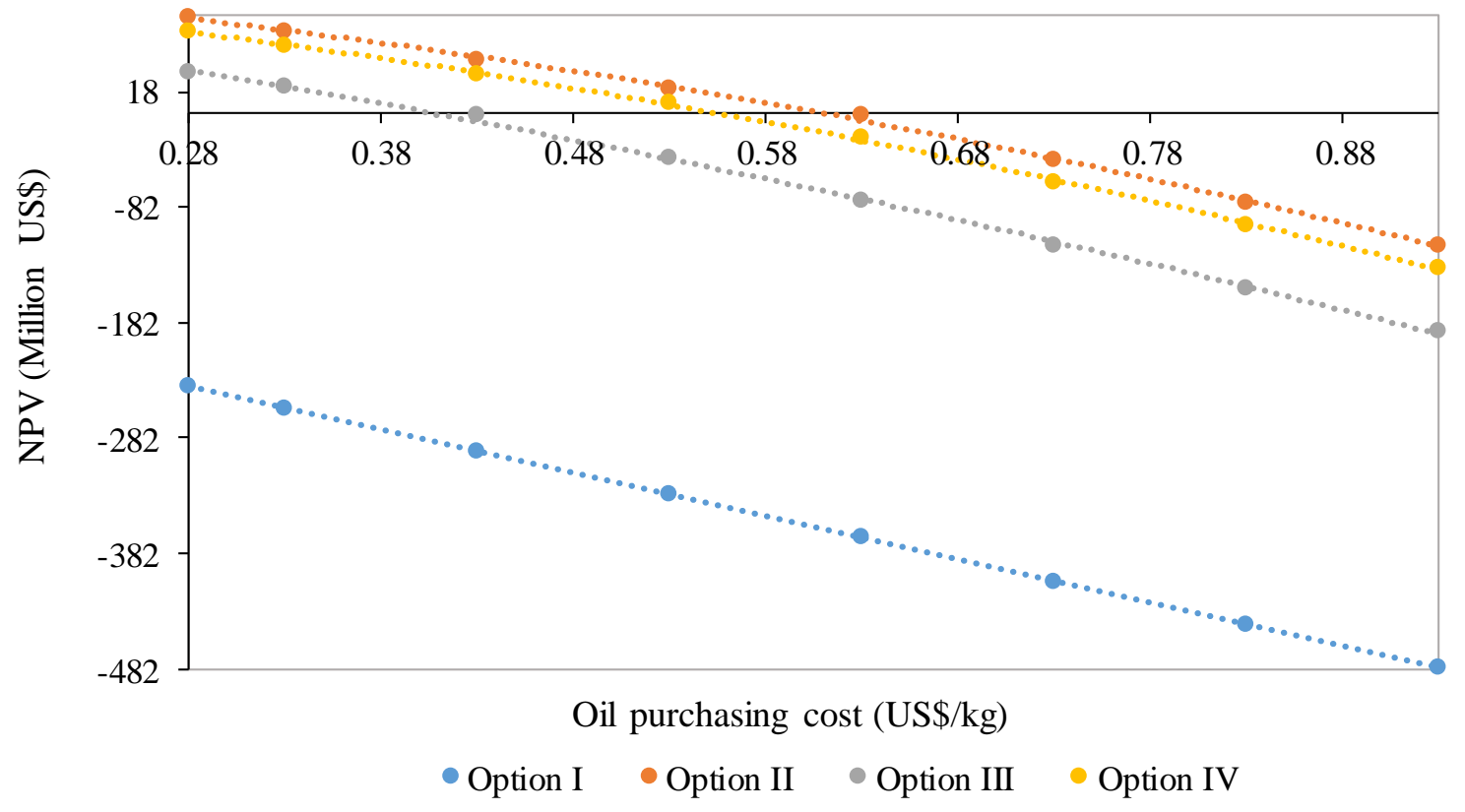

Figure 5. Effect of change of oil purchasing cost on NPV (net present value). 


\subsubsection{Effect of Change of Biodiesel Selling Price on NPV}

The changing trend of the technology options towards the variation of the market values of biodiesel price was almost similar. Option I was unprofitable for the considered ranges of biodiesel selling prices. For this option to be economically feasible, biodiesel should be sold at a very high price $(1.8 \mathrm{US} \$ / \mathrm{kg})$, which is practically impossible. On the contrary, technology option IV could be economically feasible, with almost half of this price $(0.97 \mathrm{US} \$ / \mathrm{kg})$. This designates that the production of biodiesel fuel using technology option I should be subsidized to make the fuel economically competitive with fossil diesel in the market. For the biodiesel selling price range considered, option II was found to be more tolerant of the possible fluctuation of biodiesel price and could still be economically feasible at a biodiesel price as low as 0.77 US $\$ / \mathrm{kg}$. Figure 6 indicates the effect of variation of the biodiesel selling price on NPV of the technology options.

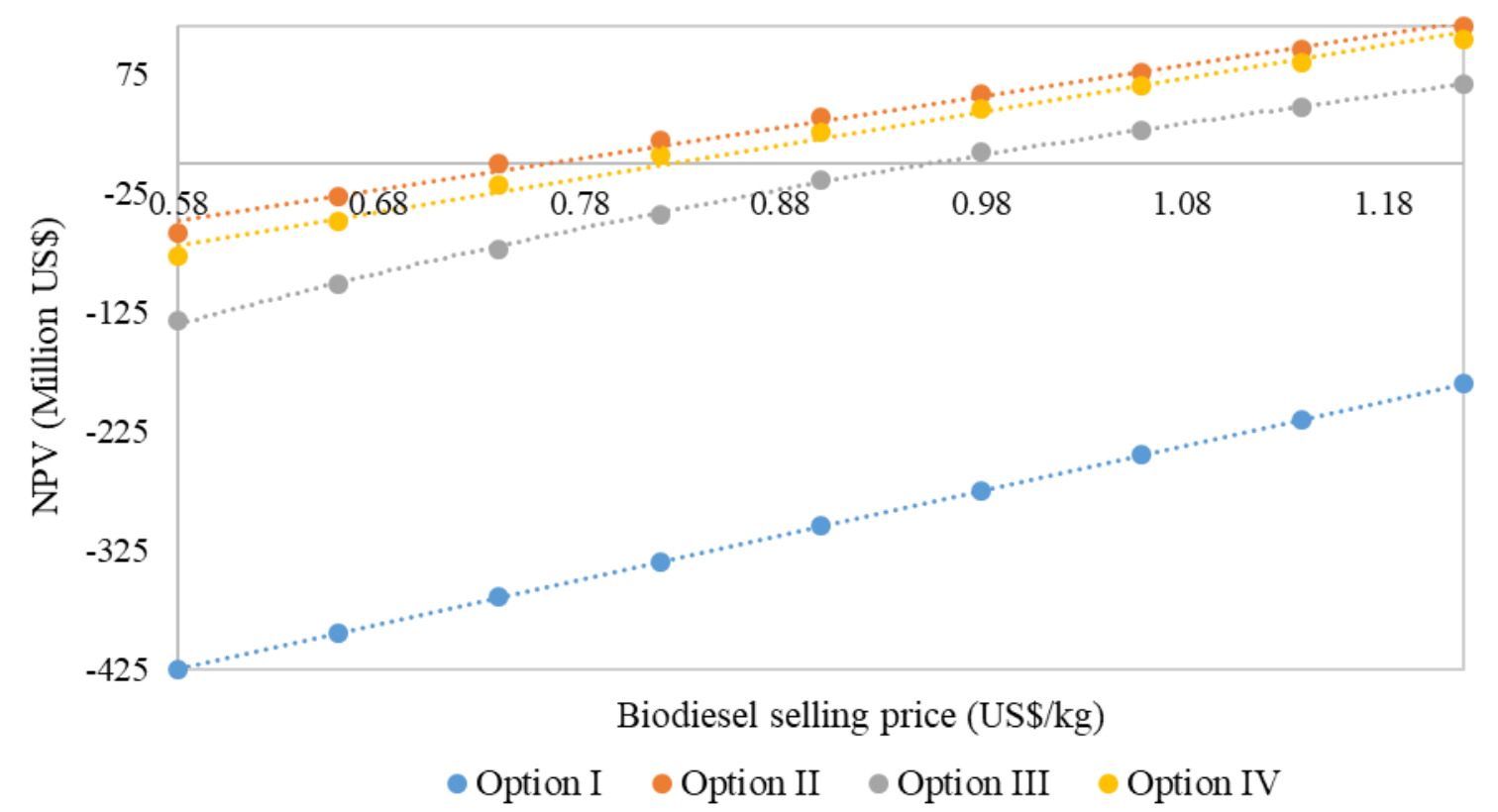

Figure 6. Effect of change of biodiesel selling price on NPV.

\subsubsection{Effect of Change of Catalyst Purchasing Cost on NPV}

The entire techno-economic comparison was among these four catalyst technologies. Thus, evaluating the effect of the market values of the four catalyst types could give reasonable ground for selecting the technology option that is more tolerant of fluctuating cost of materials in the market. The trend at which the NPV changes with the catalyst cost was almost the same for all technological options. However, some get negative NPV at very low-cost values and some at relatively higher values. For instance, an option I could still be economically feasible for about $61 \mathrm{US} \$ / \mathrm{kg}$ cost of an enzyme catalyst. This was mainly due to its higher reusability that could reduce the total cost of the catalyst. Nevertheless, this higher price, indicated here, is not enough to buy the very expensive enzyme catalysts, especially immobilized ones [54]. This demands more investigation on enzyme catalysts, which could be produced with a cost as low as $60 \mathrm{US} \$ / \mathrm{kg}$ while possessing the same catalytic performance as indicated here. Option III was found to be the most sensitive towards a change in the value of catalyst purchasing cost. It was economically feasible for a catalyst cost of less than $4.1 \mathrm{US} \$ / \mathrm{kg}$. Option IV got its negative NPV for a catalyst cost of more than 5 US $\$ / \mathrm{kg}$. The cheapest catalyst was the bulk $\mathrm{CaO}$ catalyst in option II. It could be prepared from wastes, such as eggshell, crab shell, and river snail shell, among others. The cheap cost and higher reusability of the $\mathrm{CaO}$ catalyst made option II more tolerant of the possible fluctuations of catalyst purchasing cost in the market. It got its negative NPV for a catalyst cost more than 7 US $\$ / \mathrm{kg}$, which seems to be far from its current market 
value, as indicated in Table 2. Figure 7 shows the effect of variation of catalyst cost on the NPV of each technology option.
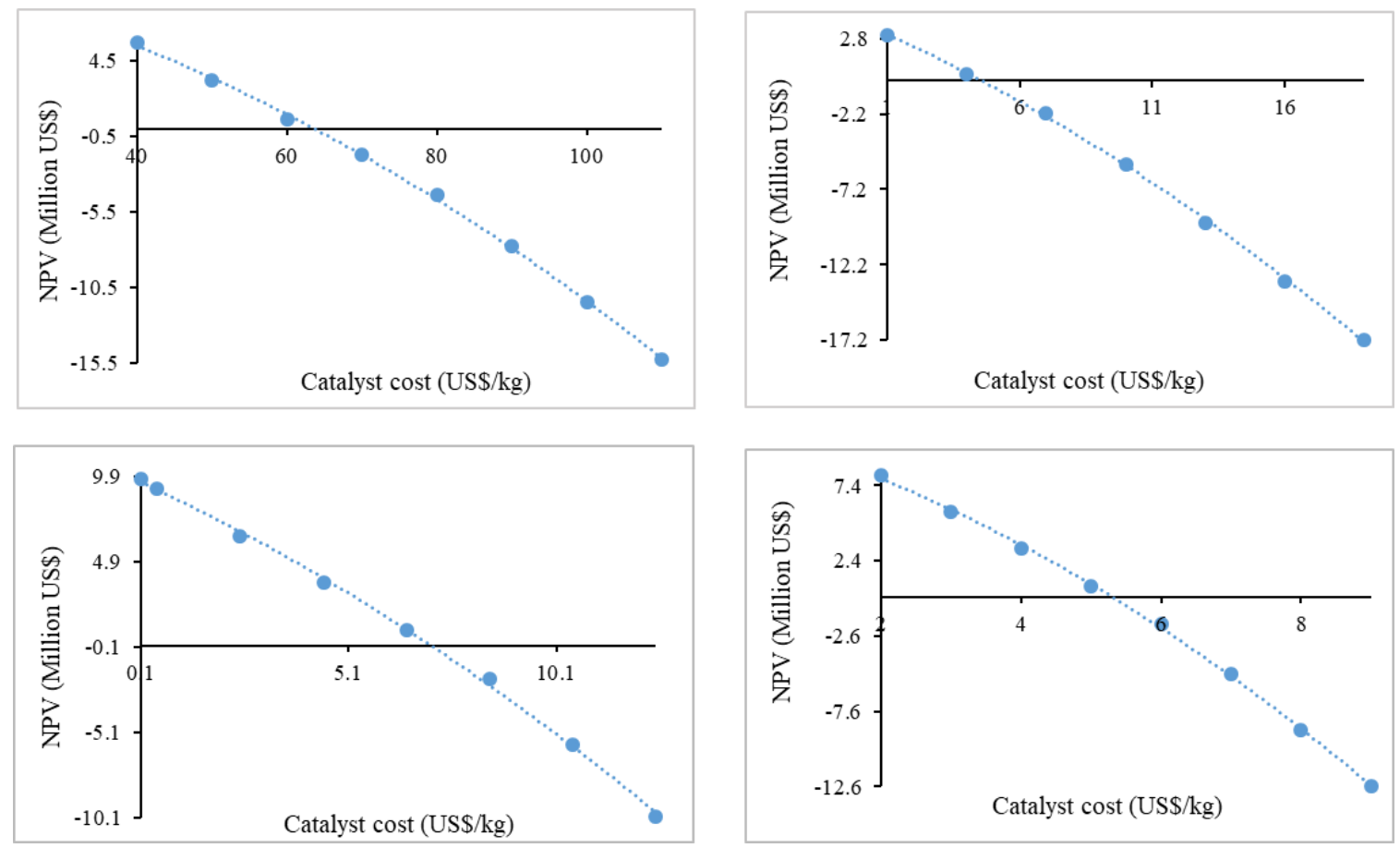

Figure 7. Effect of change of catalyst purchasing cost on NPV of each production technology option.

\section{Conclusions}

All the studied technology options could produce fuel quality biodiesel and pure glycerol. Their technical performance regarding the quantity of biodiesel per amount of oil feedstock was almost the same. Economically, the enzyme-catalyzed option was not feasible, mainly due to the very high cost of the enzyme catalyst and a larger volume of the reactor. The second expensive technology was the ionic liquid-catalyzed option. This is because it had the second-largest reactor volume and a greater number of equipment required to get fuel quality biodiesel. The bulk $\mathrm{CaO}$-catalyzed option was the most efficient in economic terms as it attained higher positive NPV, higher IRR, higher gross margin, higher ROI, and minimum total capital investment cost. The enzyme-catalyzed option was not economically feasible for all possible ranges of biodiesel price and oil cost considered. The enzyme catalyst had to be bought for less than $60 \mathrm{US} \$ / \mathrm{kg}$ for the process to be economically feasible at all. The bulk CaO-catalyzed option was the most tolerant of the change in the price of biodiesel, oil cost, and catalyst cost. It indicated profitability at a biodiesel price as low as $0.74 \mathrm{US} \$ / \mathrm{kg}$, oil purchasing cost as high as $0.70 \mathrm{US} \$ / \mathrm{kg}$, and catalyst cost as high as $7 \mathrm{US} \$ / \mathrm{kg}$.

Author Contributions: Conceptualization, S.N.G. and J.M.M.; Methodology, S.N.G. and J.M.M.; software, S.N.G. and J.M.M.; validation, S.N.G., T.H.-E., and M.T.T.; formal analysis, S.N.G. and J.M.M.; investigation, S.N.G. and J.M.M.; resources, M.T.T.; writing—original draft preparation, S.N.G. and J.M.M.; writing—review and editing, T.H.-E., M.T.T., and J.M.M.; supervision, T.H.-E., M.T.T., and J.M.M.; project administration T.H.-E. and M.T.T.; funding acquisition, T.H.-E. and M.T.T.

Funding: The financial support is from the Norad/EnPe project entitled "Research and Capacity Building in Clean and Renewable Bioenergy in Ethiopia", with Agreement No. 2015/8397 to the Norwegian University of Life Sciences (NMBU).

Acknowledgments: The financial support from the Norad/EnPe project entitled "Research and Capacity Building in Clean and Renewable Bioenergy in Ethiopia", Agreement No. 2015/8397 to the Norwegian University of Life Sciences (NMBU), is gratefully acknowledged. 
Disclaimer: The authors are not responsible for any decision that might be made using results from the process options. The process options specified in this study are merely for research purposes. If anyone needs further clarification or wants to use the result for specific applications, please contact the authors for more information concerning the limitations and scope of the designs.

Conflicts of Interest: All authors declare no conflicts of interest in this paper.

\section{References}

1. IAE. World Energy Outlook 2018, Excutive Summary. International Energy Agency, France by DESK. 2018. Available online: https://www.iea.org/weo2018/ (accessed on 10 October 2019).

2. Niculescu, R.; Clenci, A.; Iorga-Siman, V. Review on the Use of Diesel-Biodiesel-Alcohol Blends in Compression Ignition Engines. Energies 2019, 12, 1194. [CrossRef]

3. Chattopadhyay, S.; Sen, R. Fuel properties, engine performance and environmental benefits of biodiesel produced by a green process. Appl. Energy 2013, 105, 319-326. [CrossRef]

4. Bajpai, D.; Tyagi, V.K. Biodiesel: Source, production, composition, properties and its benefits. J. OLEo Sci. 2006, 55, 487-502. [CrossRef]

5. Arbab, M.I.; Masjuki, H.H.; Varman, M.; Kalam, M.A.; Imtenan, S.; Sajjad, H. Fuel properties, engine performance and emission characteristic of common biodiesels as a renewable and sustainable source of fuel. Renew. Sustain. Energy Rev. 2013, 22, 133-147. [CrossRef]

6. Atadashi, I.M.; Aroua, M.K.; Abdul, A.A.R.; Sulaiman, N.M.N. The effects of catalysts in biodiesel production: A review. J. Ind. Eng. Chem. 2013, 19, 14-26. [CrossRef]

7. Leung, D.Y.; Wu, X.; Leung, M.K. A review on biodiesel production using catalyzed transesterification. Appl. Energy 2010, 87, 1083-1095. [CrossRef]

8. Yusuf, N.; Kamarudin, S.; Yaakub, Z. Overview on the current trends in biodiesel production. Energy Convers. Manag. 2011, 52, 2741-2751. [CrossRef]

9. Helwani, Z.; Aziz, N.; Bakar, M.; Mukhtar, H.; Kim, J.; Othman, M. Conversion of Jatropha curcas oil into biodiesel using re-crystallized hydrotalcite. Energy Convers. Manag. 2013, 73, 128-134. [CrossRef]

10. Gebremariam, S.N.; Marchetti, J.M. Biodiesel production technologies: Review. AIMS Energy 2017, 5, 425-457. [CrossRef]

11. Semwal, S.; Arora, A.K.; Badoni, R.P.; Tuli, D.K. Biodiesel production using heterogeneous catalysts. Bioresour. Technol. 2011, 102, 2151-2161. [CrossRef]

12. Borges, M.; Díaz, L. Recent developments on heterogeneous catalysts for biodiesel production by oil esterification and transesterification reactions: A review. Renew. Sustain. Energy Rev. 2012, 16, 2839-2849. [CrossRef]

13. Avhad, M.R.; Gangurde, L.S.; Sanchez, M.; Bouaid, A.; Aracil, J.; Martínez, M.; Marchetti, J.M. Enhancing Biodiesel Production Using Green Glycerol-Enriched Calcium Oxide Catalyst: An Optimization Study. Catal. Lett. 2018, 148, 1169-1180. [CrossRef]

14. Marwaha, A.; Rosha, P.; Mohapatra, S.K.; Mahla, S.K.; Dhir, A. Waste materials as potential catalysts for biodiesel production: Current state and future scope. Fuel Process. Technol. 2018, 181, 175-186. [CrossRef]

15. Lam, M.K.; Lee, K.T.; Mohamed, A.R. Homogeneous, heterogeneous and enzymatic catalysis for transesterification of high free fatty acid oil (waste cooking oil) to biodiesel: A review. Biotechnol. Adv. 2010, 28, 500-518. [CrossRef]

16. Marchetti, J.M.; Pedernera, M.N.; Schbib, N.S. Production of biodiesel from acid oil using sulfuric acid as catalyst: Kinetics study. Int. J. Low-Carbon Technol. 2010, 6, 38-43. [CrossRef]

17. Miao, X.; Li, R.; Yao, H. Effective acid-catalyzed transesterification for biodiesel production. Energy Convers. Manag. 2009, 50, 2680-2684. [CrossRef]

18. Chouhan, A.S.; Sarma, A. Modern heterogeneous catalysts for biodiesel production: A comprehensive review. Renew. Sustain. Energy Rev. 2011, 15, 4378-4399. [CrossRef]

19. Correia, L.M.; Saboya, R.M.A.; Campelo, N.D.S.; Cecilia, J.A.; Rodríguez-Castellón, E.; Cavalcante, C.L.; Vieira, R.S. Characterization of calcium oxide catalysts from natural sources and their application in the transesterification of sunflower oil. Bioresour. Technol. 2014, 151, 207-213. [CrossRef] 
20. Marinković, D.M.; Stanković, M.V.; Veličković, A.V.; Avramović, J.M.; Miladinović, M.R.; Stamenković, O.O.; Veljković, V.B.; Jovanović, D.M. Calcium oxide as a promising heterogeneous catalyst for biodiesel production: Current state and perspectives. Renew. Sustain. Energy Rev. 2016, 56, 1387-1408. [CrossRef]

21. Boey, P.-L.; Ganesan, S.; Maniam, G.P.; Khairuddean, M. Catalysts derived from waste sources in the production of biodiesel using waste cooking oil. Catal. Today 2012, 190, 117-121. [CrossRef]

22. Kaewdaeng, S.; Sintuya, P.; Nirunsin, R. Biodiesel production using calcium oxide from river snail shell ash as catalyst. Energy Procedia 2017, 138, 937-942. [CrossRef]

23. Bajaj, A.; Lohan, P.; Jha, P.N.; Mehrotra, R. Biodiesel production through lipase catalyzed transesterification: An overview. J. Mol. Catal. B Enzym. 2010, 62, 9-14. [CrossRef]

24. Hama, S.; Kondo, A. Enzymatic biodiesel production: An overview of potential feedstocks and process development. Bioresour. Technol. 2013, 135, 386-395. [CrossRef] [PubMed]

25. Cervero, J.M.; Alvarez, J.R.; Luque, S. Novozym 435-catalyzed synthesis of fatty acid ethyl esters from soybean oil for biodiesel production. Biomass Bioenergy 2014, 61, 131-137. [CrossRef]

26. Tongboriboon, K.; Cheirsilp, B.; H-Kittikun, A. Mixed lipases for efficient enzymatic synthesis of biodiesel from used palm oil and ethanol in a solvent-free system. J. Mol. Catal. B Enzym. 2010, 67, 52-59. [CrossRef]

27. Andreani, L.; Rocha, J.D. Use of ionic liquids in biodiesel production: A review. Braz. J. Chem. Eng. 2012, 29, 1-13. [CrossRef]

28. Feng, Y.; Qiu, T.; Yang, J.; Li, L.; Wang, X.; Wang, H. Transesterification of palm oil to biodiesel using Brønsted acidic ionic liquid as high-efficient and eco-friendly catalyst. Chin. J. Chem. Eng. 2017, 25, 1222-1229. [CrossRef]

29. Ullah, Z.; Bustam, M.A.; Man, Z. Biodiesel production from waste cooking oil by acidic ionic liquid as a catalyst. Renew. Energy 2015, 77, 521-526. [CrossRef]

30. Banković-Ilić, I.B.; Miladinović, M.R.; Stamenković, O.S.; Veljković, V.B. Application of nano CaO-Based catalysts in biodiesel synthesis. Renew. Sustain. Energy Rev. 2017, 72, 746-760. [CrossRef]

31. Bet-Moushoul, E.; Farhadi, K.; Mansourpanah, Y.; Nikbakht, A.M.; Molaei, R.; Forough, M. Application of $\mathrm{CaO}$-Based/Au nanoparticles as heterogeneous nanocatalysts in biodiesel production. Fuel 2016, 164, 119-127. [CrossRef]

32. Colombo, K.; Ender, L.; Barros, A.A.C. The study of biodiesel production using $\mathrm{CaO}$ as a heterogeneous catalytic reaction. Egypt. J. Pet. 2017, 26, 341-349. [CrossRef]

33. Granados, M.L.; Poves, M.Z.; Alonso, D.M.; Mariscal, R.; Galisteo, F.C.; Moreno-Tost, R.; Santamaria, J.; Fierro, J. Biodiesel from sunflower oil by using activated calcium oxide. Appl. Catal. B Environ. 2007, 73, 317-326. [CrossRef]

34. Maneerung, T.; Kawi, S.; Dai, Y.; Wang, C.-H. Sustainable biodiesel production via transesterification of waste cooking oil by using $\mathrm{CaO}$ catalysts prepared from chicken manure. Energy Convers. Manag. 2016, 123, 487-497. [CrossRef]

35. Niju, S.; Begum, K.M.S.; Anantharaman, N. Enhancement of biodiesel synthesis over highly active CaO derived from natural white bivalve clam shell. Arab. J. Chem. 2016, 9, 633-639. [CrossRef]

36. Dizge, N.; Keskinler, B. Enzymatic production of biodiesel from canola oil using immobilized lipase. Biomass Bioenergy 2008, 32, 1274-1278. [CrossRef]

37. Charpe, T.W.; Rathod, V.K. Biodiesel production using waste frying oil. Waste Manag. 2011, 31, 85-90. [CrossRef]

38. Luo, H.; Fan, W.; Li, Y.; Nan, G. Biodiesel production using alkaline ionic liquid and adopted as lubricity additive for low-sulfur diesel fuel. Bioresour. Technol. 2013, 140, 337-341. [CrossRef]

39. Ghiaci, M.; Aghabarari, B.; Habibollahi, S.; Gil, A. Highly efficient Brønsted acidic ionic liquid-based catalysts for biodiesel synthesis from vegetable oils. Bioresour. Technol. 2011, 102, 1200-1204. [CrossRef]

40. Ren, Q.; Zuo, T.; Pan, J.; Chen, C.; Li, W. Preparation of Biodiesel from Soybean Catalyzed by Basic Ionic Liquids [Hnmm] OH. Materials 2014, 7, 8012-8023. [CrossRef]

41. Yang, J.; Feng, Y.; Zeng, T.; Guo, X.; Li, L.; Hong, R.; Qiu, T. Synthesis of biodiesel via transesterification of tung oil catalyzed by new Brönsted acidic ionic liquid. Eng. Res. Des. 2017, 117, 584-592. [CrossRef] 
42. Baskar, G.; Soumiya, S. Production of biodiesel from castor oil using iron (II) doped zinc oxide nanocatalyst. Renew. Energy 2016, 98, 101-107. [CrossRef]

43. Degirmenbasi, N.; Coşkun, S.; Boz, N.; Kalyon, D.M. Biodiesel synthesis from canola oil via heterogeneous catalysis using functionalized CaO nanoparticles. Fuel 2015, 153, 620-627. [CrossRef]

44. Wen, L.; Wang, Y.; Lu, D.; Hu, S.; Han, H. Preparation of KF/CaO nanocatalyst and its application in biodiesel production from Chinese tallow seed oil. Fuel 2010, 89, 2267-2271. [CrossRef]

45. Yang, L.; Takase, M.; Zhang, M.; Zhao, T.; Wu, X. Potential non-edible oil feedstock for biodiesel production in Africa: A survey. Renew. Sustain. Energy Rev. 2014, 38, 461-477. [CrossRef]

46. Kumar, A.; Sharma, S. Potential non-edible oil resources as biodiesel feedstock: An Indian perspective. Renew. Sustain. Energy Rev. 2011, 15, 1791-1800. [CrossRef]

47. Avhad, M.; Sánchez, M.; Bouaid, A.; Martínez, M.; Aracil, J.; Marchetti, J.M. Modeling chemical kinetics of avocado oil ethanolysis catalyzed by solid glycerol-enriched calcium oxide. Energy Convers. Manag. 2016, 126, 1168-1177. [CrossRef]

48. Kumar, D.; Ali, A. Transesterification of Low-Quality Triglycerides over a Zn/CaO Heterogeneous Catalyst: Kinetics and Reusability Studies. Energy Fuels 2013, 27, 3758-3768. [CrossRef]

49. Wei, Z.; Xu, C.; Li, B. Application of waste eggshell as low-cost solid catalyst for biodiesel production. Bioresour. Technol. 2009, 100, 2883-2885. [CrossRef]

50. Kaur, N.; Ali, A. Kinetics and reusability of $\mathrm{Zr} / \mathrm{CaO}$ as heterogeneous catalyst for the ethanolysis and methanolysis of Jatropha crucas oil. Fuel Process. Technol. 2014, 119, 173-184. [CrossRef]

51. Liu, S.; Nie, K.; Zhang, X.; Wang, M.; Deng, L.; Ye, X.; Wang, F.; Tan, T. Kinetic study on lipase-catalyzed biodiesel production from waste cooking oil. J. Mol. Catal. B Enzym. 2014, 99, 43-50. [CrossRef]

52. Gog, A.; Roman, M.; Tosa, M.; Paizs, C.; Irimie, F.D. Biodiesel production using enzymatic transesterification-Current state and perspectives. Renew. Energy 2012, 39, 10-16. [CrossRef]

53. Deng, L.; Xu, X.; Haraldsson, G.G.; Tan, T.; Wang, F. Enzymatic production of alkyl easters through alcoholysis a critical evaluation of lipases and alcohols. J. Am. Oil Chem. Soc. 2005, 82, 341-347. [CrossRef]

54. Andrade, T.A.; Martín, M.; Errico, M.; Christensen, K.V. Biodiesel production catalyzed by liquid and immobilized enzymes: Optimization and economic analysis. Chem. Eng. Res. Des. 2019, 141, 1-14. [CrossRef]

55. Hamd, H.T. Kinetic Processes Simulation for Production of the Biodiesel Using Enzyme as catalyst. J. Nat. Sci. Res. 2016, 6, 17-22.

56. Li, Y.; Du, W.; Dai, L.; Liu, D. Kinetic study on free lipase NS81006-catalyzed biodiesel production from soybean oil. J. Mol. Catal. B Enzym. 2015, 121, 22-27. [CrossRef]

57. Bélafi-Bakó, K.; Kovács, F.; Gubicza, L.; Hancsók, J. Enzymatic Biodiesel Production from Sunflower Oil by Candida antarctica Lipase in a Solvent-free System. Biocatal. Biotransform. 2009, 20, 437-439. [CrossRef]

58. Jachmanián, I.; Dobroyán, M.; Moltini, M.; Segura, N.; Irigaray, B.; Veira, J.P.; Vieitez, I.; Grompone, M.A. Continuous Lipase-Catalyzed Alcoholysis of Sunflower Oil: Effect of Phase-Equilibrium on Process Efficiency. J. Am. Oil Chem. Soc. 2009, 87, 45-53. [CrossRef]

59. Purushothaman, S.; Kumar, A.; Tiwari, D.P. Effect of Feeding Calcium Salts of Palm Oil Fatty Acids on Performance of Lactating Crossbred Cows Asian-Aust. J. Anim. Sci. 2008, 21, 376-385.

60. Gui, M.; Lee, K.T.; Bhatia, S. Feasibility of edible oil vs. non-edible oil vs. waste edible oil as biodiesel feedstock. Energy 2008, 33, 1646-1653.

61. Gebreegziabher, Z.; Alemu, M.; Ferede, T.; Köhlin, G. The Economics of Biodiesel Production in East Africa: The Case of Ethiopia. In Energy-Agro-Food Nexus in East Africa: Bioenergies in East Africa between Challenges and Opportunities; Marco Setti, M., Zizzola, D., Eds.; ACP-EU Cooperation Programme in Higher Education (EDULINK): Lungavilla, Italy, 2016; pp. 93-108.

62. Wage-Indicator-Foundation. Salary Scale in Ethiopian Public Sector. Available online: https://mywage.org/ ethiopia/home/salary/public-sector-wages (accessed on 26 March 2019).

63. NUMBEO. Cost of Living in Ethiopia. Available online: https://www.numbeo.com/cost-of-living/country_ result.jsp?country=Ethiopia (accessed on 26 March 2019).

64. CostToTravel. Electricity Price in Ethiopia. Available online: https://www.costtotravel.com/cost/electricityin-ethiopia (accessed on 12 May 2019).

65. Peters, M.S.; Timmerhaus, K.D.; West, R.E.; Timmerhaus, K.; West, R. Plant Design and Economics for Chemical Engineers, 4th ed.; McGraw-Hill International: Singapore, 1991. 
66. Engineering, C. The Chemical Engineering Plant Cost Index. Available online: http://www.chemengonline. com/pci-home (accessed on 28 March 2019).

67. Karmee, S.K.; Patria, R.D.; Lin, C.S.K. Techno-Economic Evaluation of Biodiesel Production from Waste Cooking Oil-A Case Study of Hong Kong. Int. J. Mol. Sci. 2015, 16, 4362-4371. [CrossRef]

(C) 2019 by the authors. Licensee MDPI, Basel, Switzerland. This article is an open access article distributed under the terms and conditions of the Creative Commons Attribution (CC BY) license (http://creativecommons.org/licenses/by/4.0/). 